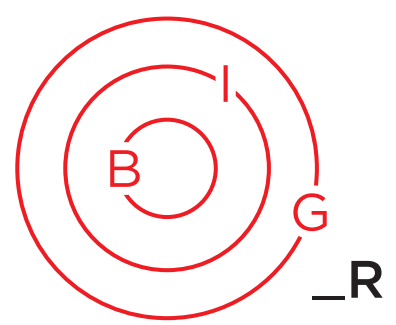

Borders in Globalization Review

Volume 2, Issue 2 (Spring/Summer 2021): 8-9

https://doi.org/10.18357/bigr22202120199

\title{
Letter of Introduction
}

\section{Dear Readers,}

The Editors of Borders in Globalization Review are pleased to share and celebrate this, our fourth biannual publication (Volume 2, Issue 2).

In this issue, you will find a special section on the poetry of borders, as well as new articles, essays, art portfolios and features, plus film reviews and book reviews. Most prominently, and breaking ground in border studies, our Chief Editor Emmanuel Brunet-Jailly and our Poetry Editor Natasha Sardzoska collaborated to produce a collection of contemporary border poetry, A World Anthology of Border Poetry: Blurred and Political, with a co-authored introduction. The collection itself features poems by 29 poets from diverse backgrounds. As the editors write, "Poetry blurs paradigms of borders, raises boundaries and destroys them at the same time".The poetry section is bookended by by academic work and visual art. First, five research articles include: an exploration of "the local" in borderland studies through comparative analysis of cases drawn from the Indian state of West Bengal (by Shibashis Chatterjee, Surya Sankar Sen, and Mayuri Banerjee); an urgent analysis of international climate policy in the context of border studies and popular discourse (by Simon Dalby); a case study of the unusual international 'exclave' of Point Roberts, an American town completely disconnected from the rest of US soil and territorially adjoining Canada (by Pierre-Alexandre Beylier); a normative pedagogical argument about teaching borders, drawing on the case of geography curriculums in Israeli middle and high schools (by Tal Yaar-Waisel); and finally, in French, an exploration of the COVID-19 lockdowns on the Spanish-Moroccan border (by Saida Latmani). After the articles and the poetry collection, readers will find our lead portfolio, featured on the cover, which unfolds in a series of drawings made by artist Francois Cayol over more than 15 years, capturing the landscapes of borders spanning the Mediterranean region to Central Asia. The images are accompanied by short first-person narratives of the artist that bely the bucolic scenary and reinsert stubborn politics, culture, and history. Next, readers can enjoy a wonderful photography portfolio featuring the borderlands and borderlanders of Lebanon, by photographer Hussein Baydoun and researcher Daniel Meier, captioned by the words and experiences of those in the photographs. Then, in an Art Feature, Elisa Ganivet (who will be serving as our Visual Art Editor starting this fall) interviews Emeric Lhuisset, a war photographer, about the concept of borders in his work. We've also included an essay on the 2020 experience of the Dutch-German border, one of the few borders in the world to stay open throughout the onset and course of the pandemic. And finally, the issue is rounded out by film and book reviews. Thanks to our Film Review Editor, Kathleen Staudt, we present a distinct pair of film reviews on two very different cinematographic works yet both futuristic border dystopias: one a Brazilian film (Bacurau, 2020), the other an Indian series on Netflix (Leila, 2020). Last but not least, readers will find two book reviews, one by Simon Dalby and one by Daniel Meier, on recent publications in border studies.

On behalf of the entire BIG team, our networks and friends, we would like to conclude this introductory letter by acknowledging the great work of our Editorial Board and other colleagues who have provided double-blind expert peer reviews to our articles and essays. The following specialists have each helped us maintain and strengthen the quality of our academic content, and for that, we thank them: 
Anasua Basu Ray Chaudhary, Nicole Bates-Eamer, Claude Beaupre, Frédérique Berrod, Pierre-Alexandre Beylier, Małgorzata Bieńkowska, Edward Boyle, Emmanuel Brunet-Jailly, Michael Carpenter, Anna Casaglia, Jaume Castan Pinos, Kimberly Collins, Irasema Coronado, Simon Dalby, Willie Eselebor, Aileen A. Espíritu, Elisa Ganivet, Sarah Green, Anna Grichting Solder, Walid Habbas, Katy Hayward, Federica Infantino, Edith Kauffer, Martin Klatt, Victor Konrad, Fabienne Leloup, Virginie Mamadouh, Lucile Medina, Daniel Meier, David Newman, Heather Nicol, Lacin Idil Oztig, Benjamin Perrier, Mirza Zulfiqur Rahman, Kathrine Richardson, Tatiana Shaban, Katarzyna Stoklosa, Dhananjay Tripathi, Martin van der Velde, Machteld Venken, and Birte Wassenberg. If any reviewers are omitted from this list, the oversight is unintentional.

Looking beyond this milestone of four issues and two years, what can readers expect from BIG_Review going forward? In addition to building on our foundations, watch for more content in diverse languages and for additional multimedia formats such as video and podcast. We've also launched our BIG_Book series and have begun collaborating with the BIG Dyads Database. We are especially excited to be part of a new BIG research project: exploring contemporary border issues in collaboration with Indigenous scholars (stay tuned!).

BIG_Review has been made possible by the Borders in Globalization research program, a Partnership Grant supported by the Social Sciences and Humanities Research Council of Canada (SSHRC \#895-2012-1022) and by the Erasmus+ programme of the European Union (see Funding and Support). We would also like to thank Inba Kehoe and colleagues at the University of Victoria Libraries for hosting the journal online, as well as to the Centre for Global Studies for hosting our offices and providing invaluable support.

Sincerely,

Michael J. Carpenter, Managing Editor Borders in Globalization Review

On behalf of Chief Editor, Emmanuel Brunet-Jailly, And the BIG team 